\title{
Pros and cons of foreign genes in crops
}

Sir - In a leading article you expressed your scepticism about leaving antibiotics genes in agricultural transgenic plants (Nature 383, 559; 1996). This view was criticized by Abigail Salyers (Nature 384, $304 ; 1996)$, who believes that it may detract from the more important fight against "the continued abuse and overuse of antibiotics by physicians, over-the-counter sale of antibiotics, and use of antibiotics in animal feed". These positions should not, however, be pitted against each other.

It is easy to understand why there should be restrictions on the direct use of antibiotics in the human environment. It may be less obvious why regulating bodies should take a critical view of harmless antibiotics genes in agricultural plants. These genes are needed to introduce the transgenic characters into the plants, but are not vital for the growth of the plants in the field. Methods can therefore be designed to remove them selectively after they have finished their task.

There are two reasons why breeders should be asked not to leave such antibiotics genes in their products. The first is that all crop plants in the future will be transformed not only once but many times. If every transformation leaves another antibiotics gene in the plant, then it will soon become difficult for the plant breeders to find new 'harmless' antibiotics genes to use. The second reason has to do with what the public expects from the new gene technology. Commercial plants with transgenic properties will become generally accepted only if the arguments in favour of their use are strong and convincing. The best argument for them is, undoubtedly, the precision by which they have become altered, by comparison with, for example, classical plant breeding. But if gene technology is to be presented as a clean technology, then it must be clean. From personal experience in the Swedish Gene Technology Board, I know how difficult it is to argue for a new crop variety containing an interesting character if it also carries some antibiotics gene of no relevance to the needs of the farmer or the consumer.

So setting high standards for new transgenic plant varieties is not only a question about human health. It is also a way to protect a vital new technology against shortsighted uses that may later lead to severe setbacks.

\section{Bengt O. Bengtsson*}

Department of Genetics,

Silvegatan 29, S-223 62 Lund, Sweden

e-mail:bengt_olle.bengtsson@gen.lu.se

*Address until June 1997: 32 rue de Chazelles, F-75017 Paris, France.

Sir - Your News story "Europe agrees a compromise on food labels" (Nature 384, $502-503$; 1996) pointed out that consumer, food industry and environmental groups have weighed in with opinions on the newly proposed compromise on labelling of genetically modified foods in Europe. Conspicuously absent from the article was any mention of views from within the science community about an issue that has fundamental scientific components.

Although disclosure of the contents of food is an important issue, the potential categorization of food into genetically modified and non-modified groups warrants more discussion.

For example, triticale, a polyploid plant containing full copies of both rye and wheat genomes, was developed 60 years ago and is now grown on more than a million hectares in Canada, Mexico and eastern Europe.
Modern plums contain chromosomes from cherry plums and blackthorn. Russian wheat has genes from both rye and wild wheat grass, and French plant breeders have introduced fungal eyespot diseaseresistance genes from goat grass into French domestic wheats. This is a sampling of a much longer list illustrating that many present-day crops used to produce food for humans have for years contained foreign genes, and could arguably be considered novel foods, without the application of recombinant DNA technology.

Newer transformation technologies clearly expand the range of foreign genes that can be introduced into crops, but the public debate centres principally on food safety issues. The perceived novelty of 'foreign' genes in foods may be responsible, at least in part, for concern about safety for human consumption and for the environment.

The interspecific genetic modification of foods is clearly not inherently new. Those writing regulations relating to a scientific determination of safety of foods should give significant weight to input from the scientific community in addition to concerns of other interests. The more the focus is kept on safety of the product for humans and the environment, with decisions being made on the basis of the soundest scientific findings rather than on novelty, the better the result should be for consumers and the environment.

\section{Donald R. Ort}

(President, American Society of Plant Physiologists)

USDA/Agricultural Research Service and University of Illinois,

Urbana, Illinois 61801-3838, USA

e-mail:d_ort@uiuc.edu

\section{Climate of mistrust}

Sir - In his review of Andrew Rowell's book Green Backlash, Julian Morris appears to have constructed a straw man and set about burning it (Nature 384, 325; 1996). Morris is eloquent and correct in his observations on the scientific method and the importance of rigorous criticism in science. But that is not the subject of Green Backlash.

My reading of the book was as an attempt, inter alia, to examine the way in which scientific knowledge is translated into a policy response and how this is open to abuse. As Morris says, "the possibility always exists that an alternative, better, theory might be found". The climatechange negotiations have been bedevilled by well-organized lobbyists who have sought to use this argument as a reason to avoid or delay action. But policy-makers have to act, and cannot delay judgements in the face of uncertainty. Even a decision to do nothing is to act as if you believe there is no cause for concern. All decisions require a working hypothesis, and, for climate change, Rowell is right to argue that the basis of policy should be that it is happening and is dangerous. This is not, however, to claim that the working hypothesis is an incontrovertible truth.

In fact, the proper application of scientific method strengthens the case for strong action to respond to climate change. This is because the alternative hypotheses that attempt to explain how anthropogenic greenhouse gas emissions do not lead to rising atmospheric concentrations and how these do not increase radiative forcing and surface temperature are very poor and challenged by plenty of confounding evidence.

These other hypotheses have so little credibility that their proponents, of whom Morris is one, have had to form the European Science and Environment Forum in order to publish them. It is not surprising he did not like Green Backlash, given that its purpose is to unmask such organizations and examine their motives.

Clive Bates

International Institute for

Energy Conservation - Europe,

1-2 Purley Place,

London N1 1QA, UK 